\title{
SISTEM INFORMASI PENGOLAHAN BANK SAMPAH DURIAN 3 BERBASIS JAVA
}

\author{
Aditia Pratama1, Ahmad Suryadi², Ari Irawan ${ }^{3}$ \\ ${ }^{1,2,3}$ Universitas Indraprasta PGRI \\ Jl. Raya Tengah No. 80, Kel. Gedong, Kec. Pasar Rebo, Jakarta Timur 13760, Jakarta \\ 1. pratamaaditia938@gmail.com, ${ }^{2}$ yadi281282@gmail.com, ${ }^{3}$ ari_irawan@unindra.ac.id
}

\begin{abstract}
ABSTRAK
Tujuan penelitian adalah untuk mengetahui bagaimana prosedur transaksi pengolahan yang sedang berjalan di Bank Sampah Durian 3 dan membantu lembaga tersebut dalam melakukan pemrosesan transaksi pengolahan sehingga dapat memberitahukan tentang laporan data transaksi yang tersedia dan menyajikan pengolahan data tentang barang yang masuk dengan cepat dan akurat sehingga dapat menghasilkan informasi yang tepat dan sesuai dengan kebutuhan. Metode penelitian yang digunakan dalam sistem informasi ini adalah metode Grounded Research yaitu metodologi penelitian kualitatif yang menekankan penemuan teori dari data observasi empirik di lapangan dengan metoda induktif menemukan teori dari sejumlah data, Tahapan penelitian dilakukan observasi dan wawancara langsung dengan ketua perihal untuk menyesuaikan keinginan dalam sistem informasi pengolahan bank sampah. Dalam hal lain juga mendeskripsikan penelitian dengan menggunakan referensi serta buku dan media lainnya yang memuat informasi yang dibutuhkan. Hasil penelitian Sistem informasi pengolahan ini diharapkan dapat membantu penggunanya dalam pemrosesan transaksi barang menjadi lebih cepat, efektif dan efisien.
\end{abstract}

Kata Kunci :sistem informasi,Pengolahan,Bank Sampah

\begin{abstract}
The purpose of the research is to find out how the transaction processing procedures are currently running at the Durian 3 Waste Bank and assist the institution in processing transaction processing so that it can inform about available transaction data reports and present data processing about incoming goods quickly and accurately so that it can produce accurate and appropriate information. The research method used in this information system is themethod, Grounded Research which is a qualitative research methodology that emphasizes the discovery of theory from empirical observation data in the field with the inductive method finding theory from a number of data, The stages of the research are observation and direct interviews with the head of the subject to adjust the wishes in the waste bank processing information system. In other cases, it also describes research using references as well as books and other media that contain the required information. Research results This processing information system is expected to assist users in processing goods transactions more quickly, effectively and efficiently.
\end{abstract}

Keywords: information system,Processing, Waste Bank

\section{PENDAHULUAN}

Saat ini sistem informasi sangat dibutuhkan, terutama dalam proses pelayanan, pencarian data barang dan pembuatan laporan. Permasalahan saat ini Bank Sampah Durian 3 masih menggunakan sistem manual. Dalam kasus ini masih melakukan pendataan transaksi dengan cara ditulis pada dengan cara pecatatan buku. Menurut (Mardinata \& Khair, 2017) teknologi informasi dalam menunjang kinerja koperasi yaitu berupa sistem informasi. Sistem Informasi marupakan sekelompok unsur atau komponen yang erat hubungannnya satu dengan yang lain yang berfungsi bersama sama untuk mencapai tujuan.

Karena dari itu penulis mencari penelitan sebelumnya dan menemukan sebelumnya menurut (Riyanto \& Kusumastuti, 2015) permasalahan yang terjadi pada tabungan bank sampah ceria Purwokerto sering terjadinya kerepotan dalam transaksi dan laporan bulanan, sering tertukarnya jenis sampah dan harganya, harga sampah per kilo sering berubah, serta adanya backup data yang bagus untuk menanggulangi data dari nasabah maupun jumlah tabungannya.

Penulis akan membuat sebuah sistem informasi pengolahan bank sampah durian 3 . Sistem informasi ini dibuat khusus dan menyesuaikan kebutuhan pada bank sampah tersebut. Maka sistem informasi ini dibuat dengan tujuan mempermudah pencatatan data 
transaksi dan kebutuhan lain yang berhubungan dengan data bank sampah. Sehingga selain data obat akan ada juga data petugas, data nasabah ,data barang, data transaksi, dancetak laporan.

Penulis menggunakan platform Netbeans 8.2 dan MySQL dalam proses pembuatan sistem informasi ini yang bisa dibilang lebih baru dari penelitian sebelumnya. Sehingga akan lebih mudah baik dalam proses pembuatan maupun penggunaan. Sistem informasi ini juga memiliki fitur membuat transaksi untuk memudahkan pencarian data transaksi secara langsung. Fitur lain yang diberikan adalah otomatis cetak laporan namun pengguna juga dapat melakukan filter tanggal atau mengatur rentang waktu data yang ingin dicetak.

\section{METODE PENELITIAN}

Penelitian ini menggunakan metode grounded research yaitu suatu metode penelitian yang mendasarkan diri kepada fakta dan menggunakan analisa perbandingan bertujuan untuk mengadakan generalisasi empiris, menetapkan konsep-konsep, membuktikan teori dan mengembangkan teori di mana pengumpulan data dan analisa data berjalan pada waktu yang bersamaan, (Nasution, 2018).

Penelitian dilakukan di Bank Sampah Durian 3 yang beralamat di Jl. Kebagusan Kecil RT 03 RW 08, Kec. Pasar Minggu, Kota Jakarta Selatan, DKI Jakarta 12520. Dalam kurun waktu 6 bulan penulis melakukan mengumpulkan data dengan metode kualitatif. (Lidimilah \& Hermanto, 2018)

Observasi dan penelitian lapangan, metode ini dilakukan dengan cara pengamatan langsung terhadap tempat Bank Sampah durian 3, observarsi dan wawancara dengan petugas dan ketua dalam memperoleh datadata secara langsung pada objek yang diperlukan. Wawancara, metode ini dilakukan melalui tatap muka langsung dan tanya jawab dengan pihak terkait yang berhubungan dengan penelitian atau sumber data.

Serta mengajukan pertanyaan-pertanyaan dan melakukan wawancara kepada petugas dan ketua Bank Sampah Durian 3. Dengan metode ini data dapat diperoleh secara langsung oleh narasumber dan kebutuhan sistem.

\section{HASIL DAN PEMBAHASAN}

\section{Proses bisnis}

Pada proses pengolahan bank sampah yang sedang berjalan, penyimpanan data atau pengarsipan data sudah menggunakan fasilitas buku atau catatan sistem manual. Sehingga memungkinkan penyimpanan data membutuhkan banyak waktu. Adapun proses bisnis sistem berjalan yaitu pendataan barang, pendataan pemasukan, pendataan pengeluaran, dan laporan.

\section{Rancangan Sistem}

Penulis menggunakan data flow diagram (DFD Data Flow Diagram (DFD) adalah suatu diagram yang menggunakan notasi-notasi untuk menggambarkan arus dari data sistem, yang penggunaannya sangat membantu untuk memahami sistem secara logika, tersruktur dan jelas. Model ini menggambarkan sistem sebagai jaringan kerja antar fungsi yang berhubungan satu dengan yang lain dengan aliran dan penyimpan data. Bisa terjadi penurunan level dimana dalam penurunan level yang lebih rendah harus bisa merepresentasikan proses tersebut kedalam spesifikasi proses yang jelas. (Juliany et al., 2018)

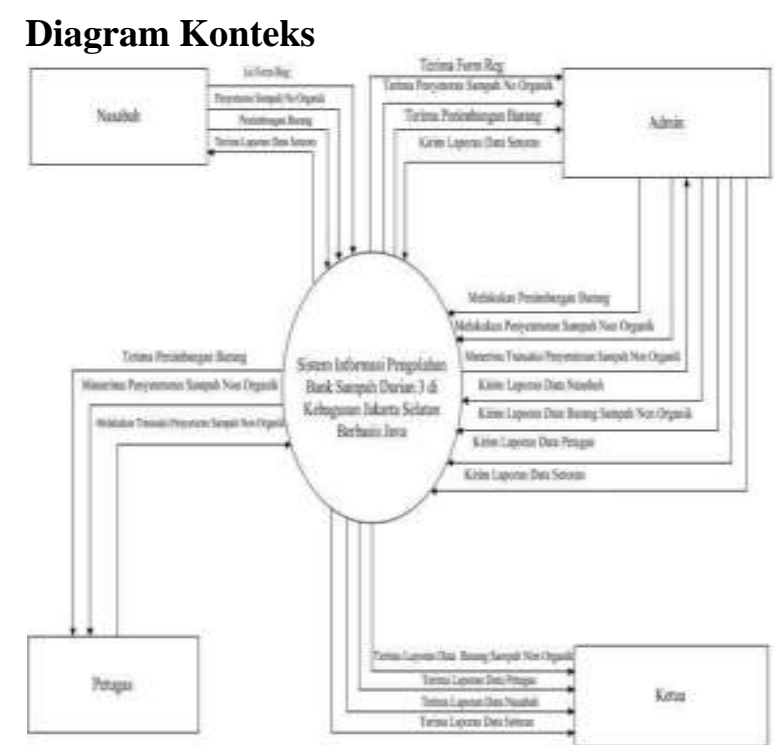

Gambar 1. Diagram Konteks

Menurut (Kusuma \& Astuti, 2017) diagram konteks merupak suatu diagram yang menggunakan notasi-notasi untuk menggambarkan arus dari data sistem, yang penggunaannya sangat membantu untuk memahami sistem secara logika, tersruktur dan jelas 


\section{Normalisasi}

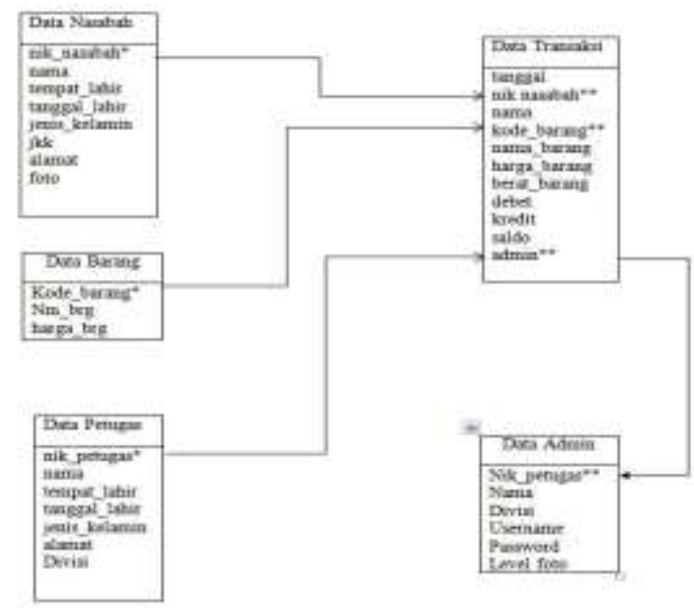

Gambar 3. Normalisasi

Menurut (Suryadi, 2019) Normalisasi merupakan proses pembentukan struktur basis data sehingga sebagian besar ambiguity bisa dihilangkan. Tahap Normalisasi dimulai dari tahap paling ringan (1NF) hingga paling ketat $(5 \mathrm{NF})$. Biasanya hanya sampai pada tingkat $3 \mathrm{NF}$ atau BCNF karena sudah cukup memadai untuk menghasilkan tabel-tabel yang berkualitas baik

\section{ERD (Entitiy Relationship Diagram)}

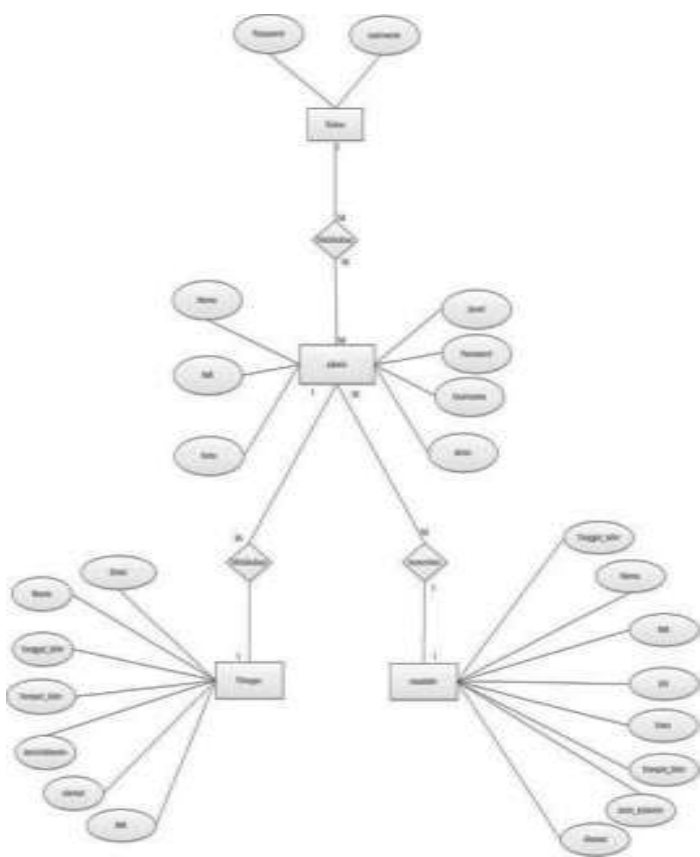

Gambar 2. ERD (Entitiy Relationship Diagram)

Menurut Antoni (2018) ERD (Entitiy Relationship Diagram) merupakan suatu model untuk menjelaskan hubungan atar data dalam basis data berdasarkan objek-objek dasar data yang mempunyai hubungan antar relasi. ERD menyediakan cara untuk mendeskripsikan perancangan basis data pada peringkat logika

\section{Tampilan Layar}

Berikut adalah hasil dari implementasi sistem informasi pengolahan bank sampah durian 3

\section{Tampilan login}

Tampilan ini merupakan halaman awal pada saat aplikasi dijalankan, menu ini berfungsi untuk masuk keadalam menu utama.

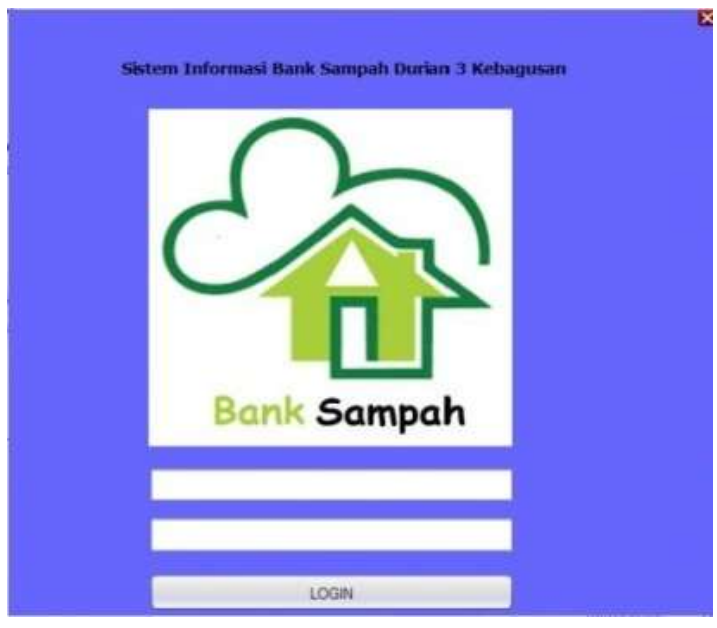

Gambar 4. Login

Pengguna diharuskan memasukan username dan password yang telah diberikan oleh ketua, lalu klik tombol masuk untuk login

\section{Tampilan menu utama}

Tampilan menu utama dari aplikasi yang dihasilkan dari penelitian ini untuk memilih menu sesuai kegiatan yang dibutuhkan dengan memilih list button yang sudah tersedia.

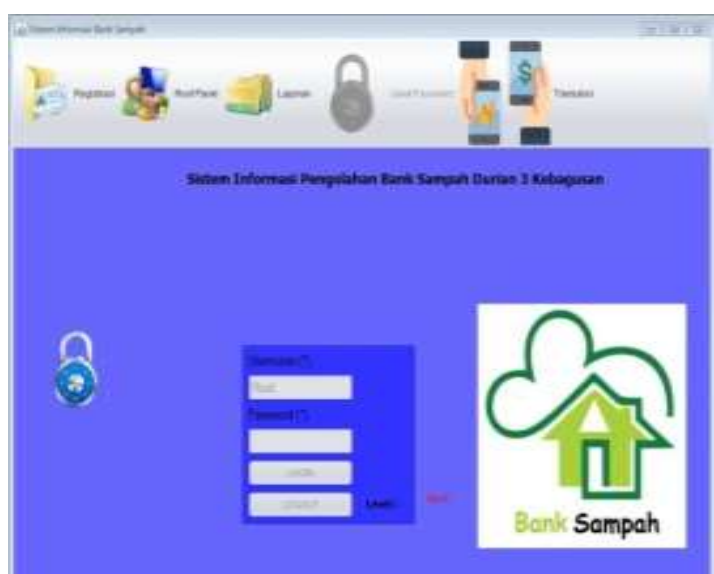

Gambar 5. Menu 
Menu utama adalah form penghubung ke semua form, dibagian atas ada beberapa sub yang bisa diklik untuk mengarahkan ke form lain

\section{Tampilan registrasi data nasabah}

Pada tampilan ini merupakan rancangan tampilan form data nasabah. Berfungsi untuk memasukkan data nasabah dan data barang.

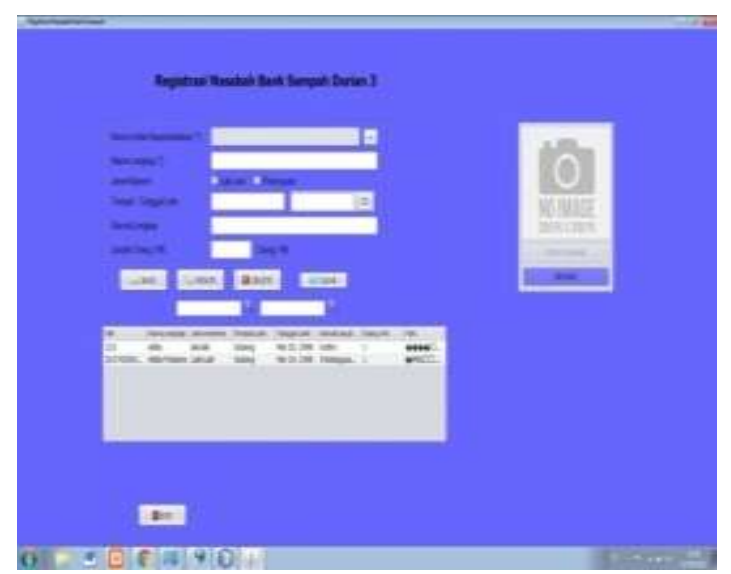

Gambar 7. Registrasi data nasabah

Pada tampilan ini admin melakukan pengisian data nasabah lalu klik save atau simpan dan akan muncul di table tersebut.

\section{Tampilan data barang}

Pada tampilan ini merupakan rancangan tampilan form data barang. Berfungsi untuk memasukkan data-data barang yang telah masuk input data barang.

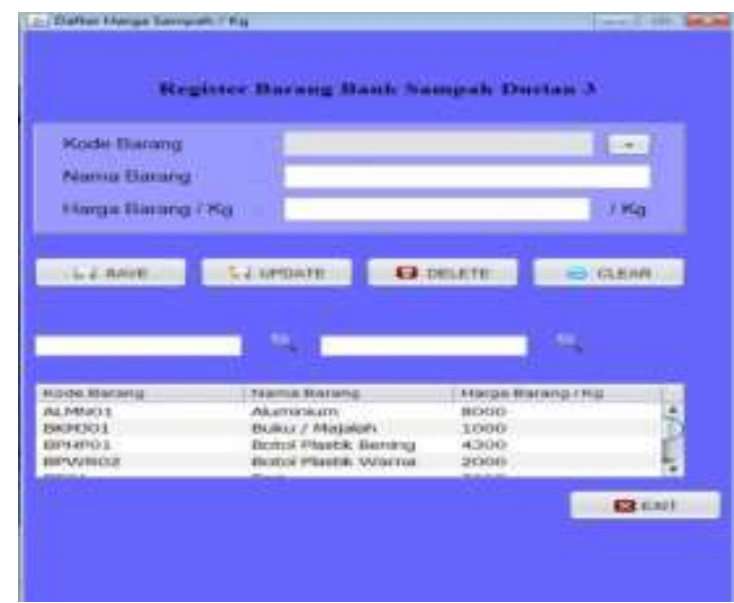

Gambar 8. Registrasi data barang

Pada tampilan ini admin melakukan pengisian data barang per kilogram lalu klik save atau simpan dan akan muncul di table tersebut

\section{Tampilan transaksi debet kredit}

Pada tampilan ini merupakan rancangan tampilan form data transaksi. Berfungsi untuk menghitung transaksi dan memasukkan datadata transaksi.

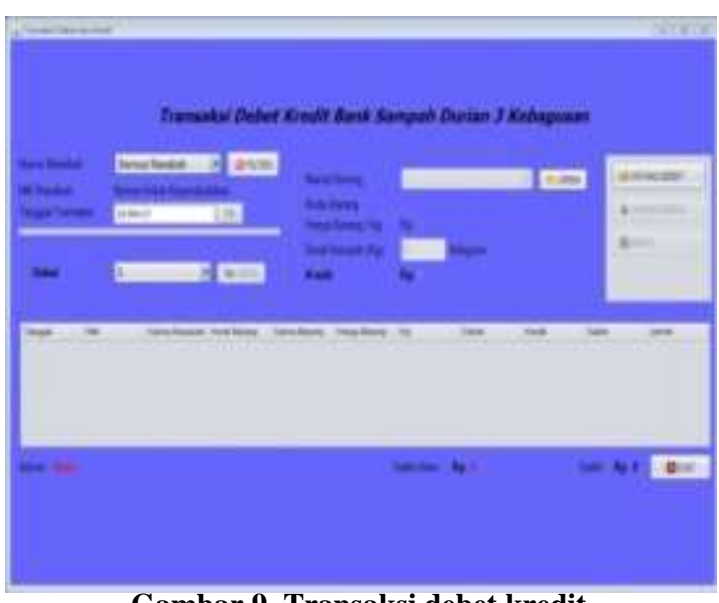

Gambar 9. Transaksi debet kredit

Masukan nama nasaba yang dicari lalu masukan nama barang, per kilo gram, klik tombol "kredit" maka data akan muncul di tabel, jika nasabah melakukan penarikan admin melakukan penarikan jumlah keuangan yang akan di ambil pada form transaksi.

\section{Tampilan Keluaran}

Berikut adalah list keluaran/uoutput dari hasil laporan yang dapat dicetak.

\section{Tampilan laporan data barang}

Tampilan ini merupakan laporan data barang.

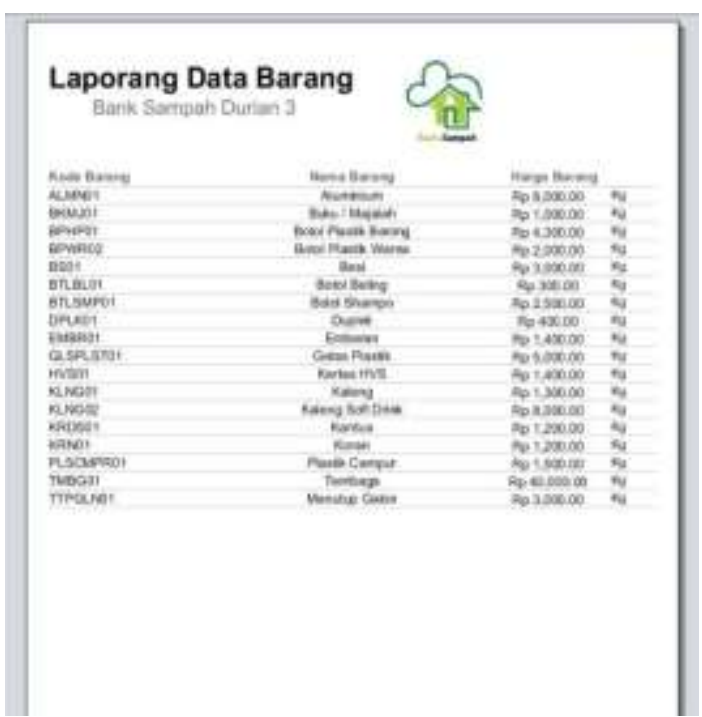

Gambar 12. Laporan data barang 
admin bisa menyimpan data laporan barang lalu pilih format penyimpanan, maka laporan akan tersimpan dalam format tersebut.

\section{Tampilan laporan data setoran}

Tampilan ini merupakan laporan data setoran nasabah.

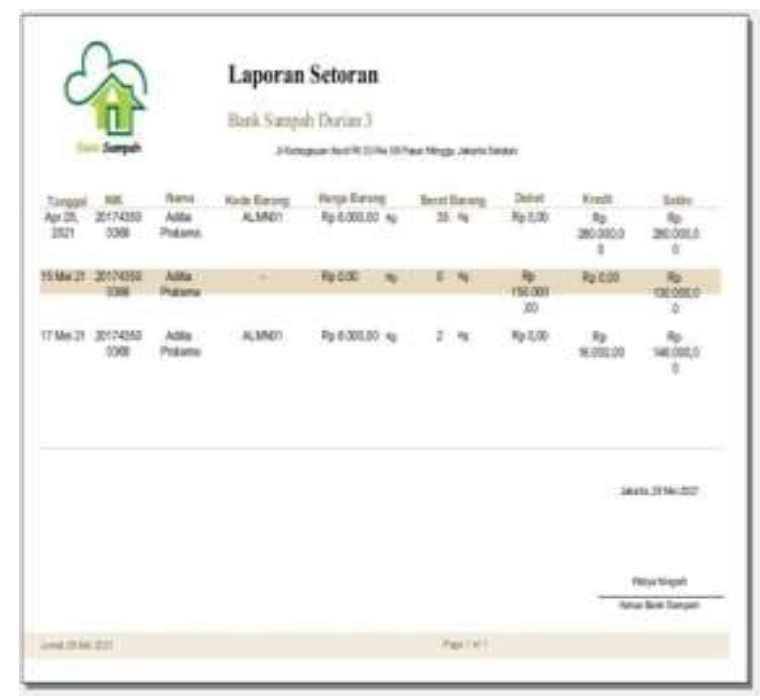

Gambar 13. Laporan data transaksi

admin bisa menyimpan data laporan transaksi setoran lalu pilih format penyimpanan, maka laporan akan tersimpan dalam format tersebut jika nasabah melakukan setoran.

\section{SIMPULAN DAN SARAN}

Dengan dibangunnya Sistem Informasi Pengolahan Bank Sampah Durian 3 ini dapat lebih mempermudah pengguna untukmemperoleh informasi seperti data petugas, data barang bekas, data transaski, dan data nasabah, dan laporan yang tepat dan tersimpan nya database terpusat. Dalam melakukan input data yang dibutuhkan dalam telitian menghitung per kg barang yang tidak layak di pakai sehingga dalam penyimpanan data tercapai hasil yang optimal. Sistem ini masih perlu dikembangkan lagi dengan melakukan proses pembuatan laporan yang secara berkala

\section{DAFTAR PUSTAKA}

Juliany, I. K., Salamuddin, M., \& Dewi, Y. K. (2018). Perancangan Sistem Informasi E-Marketplace Bank Sampah Berbasis Web. Seminar Nasional Teknologi Informasi Dan Multimedia 2018, 19-24.

Kusuma, D. P., \& Astuti, Y. (2017). Sistem Pengolahan Data Bank Sampah ( Study Kasus : Bank Sampah Bangkit Pondok I Ngemplak Sleman ). Jurnal Manajemen Dan Informatika Pelita Penusa, 21(1), 32-41.

Lidimilah, L. F., \& Hermanto, H. (2018). Sistem Informasi Bank Sampah Sukorejo Berbasis Client Server. Jurnal Ilmiah Informatika, 3(1), 193-198. https://doi.org/10.35316/jimi.v3i1.474

Mardinata, E., \& Khair, S. (2017). Membangun Sistem Informasi Pengelolahan Data Nasabah Berbasis Web Di Bank Sampah Samawa. Jurnal Matrik, 17(1), 26. https://doi.org/10.30812/matrik.v17i1.5 8

Nasution, E. Y. P. (2018). Analisis Terhadap Disposisi Berpikir Kreatif Siswa Pada Pembelajaran Matematika. Edumatika: Jurnal Riset Pendidikan Matematika, 1(1),

44. https://doi.org/10.32939/ejrpm.v1i1.217

Riyanto, A. D., \& Kusumastuti, G. (2015). Pembangunan Sistem Informasi Pengolahan Data Pada Tabungan Bank Sampah "Ceria" Purwokerto. Jurnal Telematika, 8(2), 1-17.

Suryadi, S. (2019). Implementasi Normalisasi

Dalam Perancangan Database

Relational. U-NET Jurnal Teknik Informatika, 3(2), 20-26. https://doi.org/10.52332/u-net.v3i2.7 